\title{
O SANGUE PRETO DIANTE DAS JUSTIÇAS: VILA DAS ALAGOAS, 1756
}

\author{
Le sangre negro frente a las justicias: Vila das Alagoas, 1756
}

\author{
Anne Karolline Campos Mendonça ${ }^{1}$
}

\section{RESUMO}

A América portuguesa escravista do século XVIII institucionalizou meios que previam a possibilidade da alforria para a população escravizada. Diante dessas situações, havia a imposição de uma série de condições costumeiras (e judiciais), e alicerces que dariam continuidade à manutenção da posição das camadas privilegiadas da sociedade. Problematizações que partam dos processos ou conflitos em nome de alforria podem ser substanciais para a compreensão de escravos e libertos como agentes históricos. Mas também para enxergar afundo o aparato de soluções utilizadas para manter a dominação. Neste trabalho traz-se um estudo de caso do requerimento de Joana do Rosário, mulher preta e forra que se moveu na Vila das Alagoas, em 1756, adentrando, conforme the fora possível, numa estrutura jurídica que lhe era contrária, objetivando alcançar a liberdade de membros de sua família.

PALAVRAS-CHAVE: Alagoas Colonial; Justiça e Direito; Escravidão e Liberdade; Mulher.

\section{RESUMEN}

La América portuguesa esclavista del siglo XVIII institucionalizó medios que preveían la posibilidad de la alforria para la población esclavizada. Ante estas situaciones había la imposición de una serie de condiciones acostumbradas (y judiciales) cimientos que darían con el tinte al mantenimiento de la posición de las capas privilegiadas de la sociedad. Las problemáticas que parten de los procesos o conflictos en nombre de alforria pueden ser sustanciales para la comprensión de esclavos y liberados como agentes históricos. Pero también para ver afondo el aparato de soluciones utilizadas para mantener la dominación. En este trabajo se trae un estudio de caso del requerimiento de Juana del Rosario, mujer negra y forra que se movió en la Vila das Alagoas, en 1756, adentrando, según le fuera posible, en una estructura jurídica que le era contraria, objetivando alcanzar la libertad De miembros de su familia.

PALABRAS CLAVE: Alagoas Colinial; Justicia y Derecho; Esclavitud y libertad; Mujer.

\section{Introdução}

As Conquistas Ultramarinas concretizaram um verdadeiro espaço de sociabilidades e fortes tensões entre indivíduos culturalmente distintos ${ }^{2}$. A compreensão sobre tal realidade preenchida de diversidades, no entanto, não deve ser observada equivocadamente ${ }^{3}$. Isso implica

1 Membro do Grupo de Estudos América Colonial (GEAC-UFAL), coordenado pelo Prof. Dr. Antonio Filipe Pereira Caetano. Mestra pelo Programa de Pós-Graduação em História da Universidade Federal de Alagoas. Doutoranda pelo Programa de PósGraduação em História da Universidade Federal de Pernambuco.

Email: karolline-campos@hotmail.com.

2 Sobre a existência de indivíduos de origens distintas e suas principais relações desenvolvidas na América e África, ver: THORTON, John. A África e os africanos na formação do mundo atlântico. 1400-1800. Rio de Janeiro: Elsevier, 2004. GRUZINSKI, Serge. As quatro partes do mundo. História de uma mundialização. Belo Horizonte, Editora UFMG; São Paulo, Edusp, 2014. SÁ, Elaine Garcindo de. Mestiço: entre o mito, a utopia e a história reflexões sobre a mestiçagem. Rio de Janeiro: Quartet: Faperj, 2013. HESPANHA, António Manuel. "Antigo regime nos trópicos? Um debate sobre o modelo político do império colonial português”. In. FRAGOSO, João. Gouvêa, Maria de Fátima (orgs.). Na trama das redes: política e negócios no império português, séculos XVI - XVIII. - Rio de Janeiro: Civilização Brasileira, 2010.

3 Baseados na extensa bibliografia de Gilberto Freyre, pesquisadores atualmente estão voltando à interpretações em que - em muitos momentos - os diversos grupos sociais e "raças" conseguiam viver em harmonia a partir de negociações, mais do que de 
considerar formas de pensamento político e de organização social que encaravam formas de vida, substancialmente, determinadas pelo nascimento ${ }^{4}$. Dentre essa visão de mundo advinda de preceitos jurídicos e teológicos, pode-se dizer que a alteração do estatuto de uma pessoa era quase nula, pois se tratava de um aparato que almejava apreender a verdadeira natureza do indivíduo e, por conseguinte, sua função e lugar no mundo ${ }^{5}$. Obviamente que podem ter havido agentes que utilizaram certos caminhos que contradiziam a vigência de esferas judiciais, religiosas e "naturais". Mas também é claro que essas alterações tinham o potencial para causar estranhamento ou resistência por caminhos outros que não são facilmente palpáveis.

Para trazer uma melhor assimilação das possibilidades e limites estabelecidos por normas oficiais ou costumeiras - frente à alteração de estatuto - torna-se intrigante os casos de indivíduos alforriados e sua interseção ao meio. Estudos sobre os mesmos não faltam à historiografia e é pertinente, na leitura de alguns deles, a constatação de homens e mulheres libertos (sobre)vivendo por meio de trocas mercantis, do desenvolvimento de relações sociais e da adaptação de suas formas de viver às que lhes eram impostas ${ }^{6}$. O caminho para a liberdade e suas constantes lutas pela sobrevivência geram uma série de questionamentos pertinentes, sobretudo, quando são identificados mecanismos utilizados por antigos donos (aceitas e reconhecidas pela sociedade) estabelecidos juridicamente (pela via costumeira e oficial) para manter doses

violências. Um artigo que critica esse tipo de "revisionismo" é o de MAESTRI, Mário. "Como era gostoso ser escravo no Brasil: A apologia da servidão voluntária de Kátia de Queirós Mattoso". Revista Crítica Histórica. Ano VI, no 12 , dezembro de 2015. Disponível em <http://www.revista.ufal.br/criticahistorica/attachments/article/256/Fluxo\%201.pdf > Acessado em 25/03/2017.

4 HESPANHA, António M. Imbecillitas: As bem-aventuranças da inferioridade nas sociedades de Antigo Regime. São Paulo: Annablume, 2010. HESPANHA, António Manuel. "Fundamentos antropológicos da família de Antigo Regime: os sentimentos familiares". In: HESPANHA, António Manuel (coord.). História de Portugal, o antigo regime (vol. IV). Dir. José Mattoso. Lisboa: editorial estampa, 1992. HESPANHA, António Manuel. O direito dos letrados no Império português. Florianópolis: Fundação Boiteux, 2006.

5 HESPANHA, António Manuel. "A mobilidade social na sociedade de Antigo Regime". Revista Tempo. Rio de Janeiro, nº 21, volume 11, julho de 2006.

6 ALMEIDA, Suely Creusa de. "Histórias de gente sem qualidades: mulheres de cor na capitania de Pernambuco no século XVIII". In: CABRAL, Flávio José Gomes \& COSTA, Robson. História da Escravidão em Pernambuco. Recife: UFPE, 2012. FARIA, Sheila de Castro. "Damas mercadoras: as pretas minas no Rio de Janeiro (século XVIII-1850)". In: SOARES, Mariza Carvalho. (Org.) Rotas Atlânticas da Diáspora Africana - da Baía do Benim ao Rio de Janeiro. Niterói: EDUFF, 2001. FRAGOSO, João. "Elite das senzalas e nobreza da terra numa sociedade rural do Antigo Regime nos trópicos: Campo Grande (Rio de Janeiro), 1704-1741”. In: FRAGOSO, João. GOUVÊA, Maria de Fátima. O Brasil Colonial: volume 3 (ca. 1720- ca.1821). - Rio de Janeiro: Civilização Brasileira, 2014. FURTADO, Júnia Ferreira. Chica da Silva e o contratador dos diamantes: o outro lado do mito. - São Paulo: Companhia das Letras, 2003. JÚNIOR, Waldomiro Lourenço da Silva. A Escravidão e a Lei: gênese e conformação da tradição legal castelhana e portuguesa sobre a escravidão negra na América, séculos XVI-XVIII. 2009. Dissertação (Mestrado em História) - Universidade de São Paulo, São Paulo, 2009. LARA, Silvia Hunold. Campos da Violência: escravos e senhores na Capitania do Rio de Janeiro, 1750-1808. Rio de Janeiro: Paz e Terra, 1988. LARA, Silvia Hunould. Fragmentos Setecentistas: Escravidão, cultura e poder na América Portuguesa. São Paulo: Companhia das Letras, 2007. PAIVA, Eduardo França Paiva. Escravos e libertos nas Minas Gerais do século XVIII - estratégias de resistência através dos testamentos. São Paulo: Annablume, 1995. REGINALDO, Lucilene. Os Rosário dos Angolas: irmandades de africanos e crioulos na Bahia Setecentista. São Paulo: Alameda, 2001. 
consideráveis de uma relação de interdependência entre esses agentes históricos de posições distintas ${ }^{7}$.

Nesse texto, mais especificamente, tratar-se-á da análise de parte de um processo que almejava a liberdade para seus protagonistas. O fato teria ocorrido por volta da década de 1750, na Vila das Alagoas - e Comarca de mesmo nome situada na Capitania de Pernambuco - e tomou forma a partir de um requerimento de Joana do Rosário, mulher preta forra, com um despacho de 16 de fevereiro de 1756. As interpretações aqui contidas levaram em consideração uma perspectiva dialética. Dissecou-se a fonte utilizada para o estudo (na medida do possível, apesar de muito corroída $^{8}$ ), de modo a trabalhar nas problematizações possíveis a partir da formação de seu discurso $^{9}$. Adiante-se que não se trata de uma documentação de cunho exclusivamente jurídico e que há de se considerar a probabilidade de ter sido o único momento/requerimento (mas o momento clímax) das ações e investidas de Joana em nome de salvar membros de sua família da escravidão ${ }^{10}$. Porém, as narrativas contidas ali revelam uma verdadeira saga de uma mulher forra que se via "livre", mas que ansiava em proporcionar o mesmo estatuto jurídico à sua filha e seus netos.

Certamente o Ouvidor da Comarca das Alagoas foi informado sobre o requerimento de Joana. Pelo menos essa é a única pista que pôde ser encontrada, em despacho, com referência a resolução do caso. Identifica-se, também, alguns aspectos que podem ser ligados à perspectiva de Joana do Rosário com relação aos seus direitos estabelecidos pelo costumeiro e pela formalidade ou existência de uma literatura jurídica. Diante da necessidade de enfrentamento de pelo menos três homens, ela buscou meios para fazer-se representar e ouvir. Adentrando no meio judicial, contudo,

7 SOARES, Márcio de Sousa. "A promessa da alforria e os alicerces da escravidão na América portuguesa". In: GUEDES, Roberto. Dinâmica imperial no Antigo Regime português: escravidão, governos, fronteiras, poderes, legados: Séc. XVII-XIX. Rio de Janeiro: Mauad X, 2011. SILVA, Maria Beatriz Nizza da. "A cultura explícita”. In: MAURO, Frédéric (coord.). Nova história da expansão portuguesa: o império luso-brasileiro, 1620-1750. Direção de Joel Serrão e A. H. de Oliveira Marques. - Lisboa: Editorial Estampa, 1991.

8 Agradeço ao historiador Alex Rolim Machado por ter trabalhado arduamente na primeira versão de transcrição do documento base desse texto (Doc. 155 do conjunto documental Arquivo Histórico Ultramarino - Alagoas Avulsos: mais informações na nota 09). As dificuldades para a leitura e identificação de diversas palavras, na fonte, são latentes no ato de paleografar. Por conta disso, agradeço também ao Prof. Dr. A. Filipe Pereira Caetano, Professor da Disciplina de Paleografia no curso de História da Universidade Federal de Alagoas, pela segunda revisão da transcrição feita por Alex Machado. E saliento que qualquer erro paleográfico é de minha inteira responsabilidade, já que também precisei corrigir mais de uma vez a versão final da transcrição do documento para o levantamento conciso de hipóteses e para a escrita deste artigo.

9 BARDIN, Laurence. Análise de Conteúdo. Lisboa, Edições 70. O documento utilizado para a composição deste texto está presente no Catálogo de Documentos Manuscritos Avulsos referentes à Capitania de Alagoas Existentes no Arquivo Histórico Ultramarino e podem ser consultados no Centro de Pesquisa e Documentação Histórica (CPDHis), da Universidade Federal de Alagoas, onde encontram-se em formato de CD-ROM (digitalizados). A saber: Arquivo Histórico Ultramarino, Alagoas Avulsos: Documento 155 [16 de fevereiro de 1756].

10 Afirma-se isso considerando uma pesquisa nos 297 primeiros documentos do Catálogo referido na nota 08 , bem como em pesquisa feita no Arquivo Público do Estado da Bahia, em busca de registro de pedidos de Joana do Rosário registrados diretamente ao Tribunal da Relação da Bahia. 
tornou-se clara a necessidade de encaixe em modo de vida e visão de mundo que lhes proporcionasse o êxito em seus objetivos.

Vejamos, a seguir, até que ponto as principais linhas de defesa e acusação estruturadas serviram ao atendimento dos pedidos em prol de sua causa. Num turbilhão escravista era substancial para aquela mulher preta forra, preencher requisitos demonstrativos de uma realidade passível da interseção do monarca ou de seu Tribunal Superior (a Relação da Bahia). Seu desejo era ativar uma justiça de fora e isso somado a luta pela liberdade de sua filha - a escrava parda Francisca - podem revelar indícios contrastantes a respeito da vivência de uma pessoa que havia mudado de estatuto jurídico (de escrava para liberta). Ora, a existência do requerimento por si só apresenta-se como fato dado o acúmulo de pecúlio ou de relações sociais inerentes ao alcance de sua escrita e envio. Por outro lado, encontra-se uma narrativa demonstrativa de tensões cruciais e constantes que apontam aquele pedido como uma espécie de última cartada possível: não era a primeira vez que Joana batia de frente com agentes dominantes da sociedade da qual fazia parte, em busca daquela alforria.

\section{Dentro de uma realidade de Antigo Regime, até que ponto relações sociais entre indivíduos de camadas distintas fazem diferença frente o envolvimento da parte menos privilegiada em um litígio? A curiosa amizade de Úrsula e Joana.}

Úrsula de Brito, casada com Simão Luís era, ao que tudo indica a dona principal ${ }^{11}$ da escrava parda Francisca, filha da requerente. Quando Joana do Rosário pediu a interseção do rei D. José na resolução dos processos de alforria de seus descendentes, partiu da narrativa de ordem cronológica a respeito dos empecilhos que vinha tentando enfrentar. Acima dos reclames que viriam a seguir, sua causa foi fundamentada como justa com argumentação inicial, plausível e legal que apontava a existência de uma "carta de liberdade" passada por Úrsula de Brito para sua filha, já nas primeiras linhas:

Diz Joana do Rosário, preta forra [...] que tendo uma filha parda por nome Francisca [ilegível] se achava no domínio de sua Senhora Úrsula de Brito esta antes de falecer [corroído] carta de liberdade, porém como deixou a

11 A escrava podia ser parte de seu dote ou de seus bens próprios. Isso não significa que os mesmos fossem alheios aos comandos/propriedades do marido. Apenas justifica as atitudes que mais tarde serão analisadas. 
mesma carta em poder de seu marido Simão Luis este a ocultou de sorte que se serviu [corroído] servido[?] da filha da suplicante como escrava $[\ldots]^{12}$

Como pode ser visto, na citação acima, o falecimento de Úrsula pode ser compreendido à primeira vista como o primeiro empecilho a consecução dos ditames da carta de liberdade que havia sido passada em algum momento. É certo que o ocultamento do registro por parte do viúvo Simão Luís pode ser considerado como momento crucial de desestabilização de um acordo que provavelmente fora selado entre aquelas três mulheres (Úrsula, Joana e Francisca). Contudo, os primeiros questionamentos que surgem dizem respeito aos motivos que levaram a procrastinar uma decisão que teria sido tomada oficialmente e através da escrita de carta de manumissão.

As relações de Úrsula de Brito com Joana do Rosário podem ter sido decisivas para a segunda afirmar a existência de uma carta de manumissão para sua filha. Logo de início, quando é dito que Francisca "ainda se achava no domínio de sua Senhora”, a possibilidade de Joana ter sido parte da escravaria do mesmo núcleo familiar parece plausível - isso de acordo com as conexões da palavra "sua": sua de Joana, sua de Francisca ou sua de ambas? Se foi escrava de Úrsula, a suplicante pode ter servido por diversas atividades que a capacitariam a alcançar sua alforria ${ }^{13}$. Além da compra, mesmo que "a prazo", não se pode ignorar a interpretação de que sua senhora tenha lhe concedido ambas as alforrias. Essa vertente de análise não deve ser deixada de lado, visto a compra de sua própria liberdade, mais a de sua filha, poderem servir como argumento fundamental no questionamento da consecução da escravidão da parda Francisca. Contudo, em nenhum momento, no pedido que Joana do Rosário enviou ao Conselho Ultramarino, foi exposto informações a respeito da compra da carta de manumissão de Francisca, o que poderia ter sido crucial no atendimento de sua súplica. Dessa maneira, a hipótese mais concreta a ser aviltada é a de que algum acordo outro, ou negociação, foi feito entre as mulheres de distintas posições sociais em nome de libertar pelo menos a filha da subalternizada delas.

Não se pode saber que acordo foi esse através da leitura do requerimento. Mas a não ser que o acórdão tenha sido realizado a beira da morte de Úrsula de Brito (e mesmo que o fosse) por compra ou pelo desenvolvimento de algum tipo de relação "amistosa" entre aquelas personagens - não se tratava de um pacto forte o suficiente. Simão Luís foi apresentado como um

12 Arquivo Histórico Ultramarino, Alagoas Avulsos: Documento 155 [16 de fevereiro de 1756], fl. 01.

13 Como escrava de ganho, por exemplo, Joana pode ter conseguido levantar quantia necessária para alcançar sua liberdade. Ressalte-se que juntar dinheiro suficiente para pagar seu valor não era significante automático de alforria, pois se deveria contar também com a vontade do senhor em ceder a graça da liberdade. FARIA, Op. Cit., 2001, pp. 101-136. Outras possibilidades, ver: PAIVA, Op. Cit., 1995. SOARES, Op. Cit., 2011. LARA, Op. Cit., 1988. 
dos primeiros enfrentamentos necessários à Joana na busca da liberdade de sua filha, mas é provável que, na verdade, a própria Úrsula de Brito tenha agido exclusivamente em seu próprio favor ou, no mínimo, tarde demais para reaver a vida de Francisca.

Mesmo com as ínfimas informações trazidas por Joana e seu representante legal, pode-se problematizar que o que aconteceu foi uma recuperação de uma propriedade, por parte de Simão Luís só possível pela existência de mecanismos institucionalizados que previam, mas evitavam a libertação da escravatura. No caso de produção de carta de manumissão implica considerar que algum pacto foi estabelecido, mas que o mesmo impunha condições variadas que adiaram de forma letal a execução do acordo ou venda.

O segundo conflito tomaria como palco o aparelho jurídico da Comarca das Alagoas, mais precisamente, pois foi protagonizado por um agente de justiça vindo de fora. Foi designado como "o Ministro que então servia". É a denominação de "ministro" que faz crer se tratar de um oficial reinol em território luso-americano. A ex escrava após o primeiro enfrentamento contra Simão Luís viu sua filha ser atribuída a um inventário realizado pela via judicial, mas que não possuía herdeiros para contemplar. Nesse ponto, a corrosão do documento pesa para a argumentação sobre os procedimentos que levaram a exclusão das investidas de Joana do Rosário em nome de fazer valer a "carta de liberdade" a qual se referia - da produção do inventário daquela família. Não se pode afirmar com certeza se se tratava de uma falta de herdeiros que levaria a escrava Francisca à jurisdição de Simão Luís ou se a lista de bens havia sido feita quando da morte do viúvo. De uma forma ou de outra, as ações de Úrsula, o ocultamento do registro de alforria por parte de seu marido e a provável articulação de Joana para resolução de seus litígios não resultaram em êxito para sua filha.

A análise pode ser seguida, sobretudo, porque o ponto mais importante a ser evidenciado é o fato de que foi a mulher parda e escrava quem "protestou" pela sua liberdade, tendo como resposta uma negativa do dito ministro que se recusava a ouvir a filha de Joana.

E por seu falecimento foi contada no inventario posto [ilegível] público [ilegível] protestou pela sua liberdade a demanda-la em juízo [ilegível] do dito Simão Luís, a quem não ficaram herdeiros, mas não o fez assim [ilegível] porque o Ministro que então servia naquela vila não quis admitir a filha da suplicante em juízo [... $]^{14}$.

14 Arquivo Histórico Ultramarino, Alagoas Avulsos: Documento 155 [16 de fevereiro de 1756], fl. 01. 
O protesto de Francisca tomou forma diante de sua inserção num processo de arrematação. Relembre-se que não se sabe que a arrematação seria feita em prol de Simão (se este continuava vivo) ou do Ouvidor, devido à ausência de herdeiros do casal. O "ministro" que servia na Comarca das Alagoas teria renegado a mulher parda e escravizada em juízo por quais motivos? Como a resposta não consta no documento enviado provavelmente por volta de 1755 , cabe identificar as possibilidades que giram em torno de uma única ação. Fosse o oficial de justiça local ou temporário, é certo que o estigma social ${ }^{15}$ de Francisca, por si só, se apresentaria como um empecilho substancial. Apesar de residir na sede da comarca, e que isso tenha significado de que a vila estivesse em maior sintonia com as formas da Justiça ${ }^{16}$, a localização social daquela mulher parda infringiria peso considerável na consideração da potência de sua voz, subordinada, ainda, a avaliação de seu comportamento e conduta.

Após conflitos ou desentendimentos com o novo definidor do destino de Francisca, a Justiça local abriu mão de oficializar obstáculos aos seus interesses e/ou aos de Simão Luiz. Essa decisão, tomada na via judicial, pode ter sido fundamentada em conexões daqueles oficiais entre si - se os herdeiros são descritos para identificar a morte de Simão - ou com o esposo de Úrsula. Vertente sempre em aberto para casos jurídicos ultramarinos, esta forma de análise é capaz de enfatizar o questionamento chave que se quer propor. Em se tratando de acórdãos entre juízes, amizades ou representações de Francisca e sua mãe pela voz de outros indivíduos brancos daquela vila, alternariam o objetivo de manutenção das prerrogativas daqueles homens da Justiça? E se o desprezo às causas de duas mulheres negras foi baseado na posição de Simão Luiz, o pacto com as mesmas pessoas ou com a esposa falecida de Simão pendeu a balança em favor do lado mais frágil do conflito?

É claro que há a possibilidade de que tenha lhe sido negada qualquer tipo de atitude judicial que implicasse seu dono, por se tratar de um homem branco e possuidor de um estatuto moral e jurídico que o permitia adentrar nas mais variadas redes clientelares locais. Momentos como este são decisivos para se compreender que as relações cotidianas que tantos indivíduos pardos ou pretos libertos, mesmo mulheres, puderam desenvolver, não necessariamente significavam automáticos êxitos, para além de circunstâncias corriqueiras de sobrevivência ${ }^{17}$. Por mais complexo que possa

15 HESPANHA, Op. Cit., 2005, pp. 57-58. SOARES, Márcio de Sousa. “A promessa da alforria e os alicerces da escravidão na América portuguesa”. In: GUEDES, Op. Cit., 2011, pp. 35-65. LARA, Op. Cit., 1988, pp. 264-268. SILVA, Op. Cit., 1991, pp. 304-306.

16 Arquivo Histórico Ultramarino, Alagoas Avulsos, Documento 10 [26 de maio de 1712].

17 PAIVA, Op. Cit., 1995. HESPANHA, Op. Cit., 2010. 
ser, o historiador, bem como o leitor de História, deve procurar se transportar, temporalmente, para a situação da qual esta se falando e era mais ou menos a década de 1750. Não quer se dizer que naquele momento histórico, esses personagens não tenham conseguido relacionar-se com outros, advindos de camadas sociais adversas as suas. Mas é certo que nenhuma amizade, ou variados tipos de ligações amistosas que podem ter sido forjadas, entre brancos e não brancos levou a alteração da visão de mundo estabelecida naquele local histórico em que se encontrava Joana do Rosário. Uma ordem "legitimada" porque era "natural", dificulta qualquer visualização otimista sobre essas relações, concretizada entre agentes de lugares diferentes, dentro de uma vila como a de Alagoas, terem atingidos patamares sempre ou geralmente positivos em perspectivas mais formais.

Apesar de ser mencionado de maneira superficial e rápida - mas nunca neutra - essa nulidade interpretada pela via da justiça no momento em que aquelas mulheres reagiram a prossecução do testamento de Úrsula (e em outra vertente de Úrsula e Simão), por si, só concedenos pistas para a observação dos vínculos ou enlaces das mulheres com a justiça e seus agentes no âmbito colonial português. Se no corpus jurídico toda lei ou norma estava constituída para homens e mulheres, a não ser em casos de exceção devidamente indicadas ${ }^{18}$, questionamentos a respeito desse mesmo aparato judicial vem à tona quando o problema que se apresenta envolve uma mulher parda, escrava e em confronto com seu senhor e/ou com um juiz competente. A primeira resposta que se procura diz respeito a esse arcabouço de leis perante indivíduos de camadas consideradas inferiores. Ambas as formas de justiça, fosse ela secular ou eclesiástica, partiam da prerrogativa principal sobre a categorização social dos indivíduos envolvidos em pleitos. Isso significa dizer que tanto criminosos quanto vítimas eram observadas em processos jurídicos, protegidos por privilégios de nascença ou punidos mais rigidamente, tudo de acordo com as funções que ocupavam no todo que era a sociedade de Antigo Regime ${ }^{19}$.

Joana e Francisca contaram com relativo apoio de Úrsula de Brito, segundo consta em seu discurso ${ }^{20}$. Assim, num primeiro momento, e por motivos que se desconhece, as duas mulheres afirmaram ter conseguido carta de manumissão da esposa de Simão. Como o "Ministro",

18 HESPANHA, Op. Cit., 2010, pp. 101-137.

19 Ver: ALMEIDA, Cândido Mendes de. Código Filipino, ou, Ordenações e Leis do Reino de Portugal: recopiladas por mandado d'el Rey D. Filipe I / Cândido Mendes de Almeida. Ed. Fac-sim. Brasília: Senado Federal, Conselho Editorial, 2012,4 Tomos. VIDE, Sebastião Monteiro da. Constituições Primeiras do Arcebispado da Bahia. Istvan Jancsó, Pedro Puntoni (org.). - São Paulo: Editora da Universidade de São Paulo, 2010.

20 Essa ajuda da senhora é estipulada porque nenhum dono de escravo era obrigado a aceitar o valor de mercado para dar a liberdade a seus escravos. JÚNIOR, Waldomiro Lourenço da Silva. A Escravidão e a Lei: gênese e conformação da tradição legal castelhana e portuguesa sobre a escravidão negra na América, séculos XVI-XVIII. 2009. Dissertação (Mestrado em História) - Universidade de São Paulo, São Paulo, 2009, pp. 56-60. PAIVA, Op. Cit., 1995. FARIA, Op. Cit., 2001, pp. 101-136. LARA, Op. Cit., 1988. 
na época, não quis aceitar um pedido de ativação de pleito, a alternativa foi confiar em Antônio Nogueira Pinto e ceder a um acordo que, já de início, pode ser notado como desvantajoso e indicativo do que estaria por vir. Não foi importante para quem escreveu ou requereu, em nome de Joana do Rosário, apontar conexões com outros indivíduos além da falecida senhora Úrsula de Brito. Assim, a única relação mais ou menos "amistosa" desenvolvida por Joana e sua filha não foi capaz de fazer frente aos interesses de terceiros em contatar a mulher parda como escrava disponível ao remate. Foi aí que surgiu Antônio Nogueira Pinto com a possibilidade de reverter a situação desastrosa em que aquelas mulheres se encontravam, a partir de uma solução que o levava a posição de um quase benfeitor para a família de Joana.

O requerimento da preta forra em questão deu conta de enfatizar, quantas vezes foram necessárias, sobre a promessa que Nogueira Pinto lhe fizera. A um passo do remate, a única cartada que restou foi estabelecer outro acordo com um indivíduo externo ao conflito. Antônio Nogueira afirmou que remataria não apenas Francisca, mas também seu filho, Francisco, por suas próprias fazendas. Com essa proposta, Joana do Rosário pareceu ter ficado satisfeita. No entanto, o pormenor do mais novo contato social da ex escrava, era o de que compraria os cativos para "em pouco tempo" lhe conceder carta de manumissão. Esse pacto foi feito, então, sob um terreno senão movediço, substancialmente desvantajoso, visto que o ato de Úrsula ainda era ignorado e Francisca e seu filho ainda permaneceriam escravizados ${ }^{21}$.

Tais acontecimentos poderiam ser comuns na América portuguesa. Mesmo apesar de no início ter um ar romântico como em contos de ficção, em que um senhor bondoso daria sua palavra de honra ${ }^{22}$ para promover a liberdade de toda uma família escrava. A "desonestidade" do senhor (e, aqui, se toma o juízo de valor a partir do ponto de vista de Francisca) era, naqueles idos de século, uma possível cultura comum nos relacionamentos entre senhores e escravos, em que as alforrias foram utilizadas tanto em atos de piedade cristã no momento da morte, bem como ferramentas de manutenção da ordem escravista ${ }^{23}$. Apesar de terem existidos homens e mulheres escravos que tivessem noções sobre a justiça e da existência do direito, diante o acordo verbal que pouco valeria naquela situação, não se pode deixar de emitir outro juízo de valor ao categorizarmos Francisca de "ingênua". Todavia, sua obstinação em ter um caso analisado pelo Conselho

21 Arquivo Histórico Ultramarino, Alagoas Avulsos: Documento 155 [16 de fevereiro de 1756], Fl. 01 e $01 \mathrm{v}$.

22 Sobre uma ideia de honra para os homens luso-brasileros, em especial os do centro de Pernambuco, cf. MELLO, Evaldo Cabral de. O nome e o sangue: uma parábola familiar no Pernambuco colonial. $2^{\mathrm{a}}$ edição revista. - Rio de Janeiro: Topbooks, 2000, p. 27.

23 PAIVA, Op. Cit., 1995. FARIA, Op. Cit., 1998, pp. 289-354. FARIA, Op. Cit., 2001, pp. 101-136. MACHADO, Op. Cit., 2008, pp. 81-140. SOARES, Op. Cit., 2011. LARA, Op. Cit., 1988. 
Ultramarino serve para demonstrar que aquele tipo de atitude ficava no mundo ambíguo dos acordos verbais.

Há a possibilidade de Joana ou Francisca terem sentido o desejo de apelar para outras instâncias, como o Tribunal da Relação da Bahia ${ }^{24}$, nos momentos iniciais dos problemas. Nessa linha de raciocínio considera-se que as mulheres tenham, pelo menos, apontado por argumentos, atitudes ou outras formas, sobre a possibilidade de clamar esses poderes superiores mesmo ao do "ministro". Observe-se que evitar qualquer tipo de empecilho por parte de mãe ou filha seria essencial para dar prosseguimento a execução da rematação. Bens litigiosos não deveriam ser vendidos, sendo, por lei, estagnados até a resolução dos conflitos jurídicos que o qualificam de tal forma $^{25}$. Assim, Antônio Nogueira estaria não apenas de acordo com seus interesses, mas também com os dos outros personagens protagonistas envolvidos na trama, sob seu ponto de vista. Sujeitando-se a negociação com a mãe de Francisca, foi capaz de convencê-la e dar continuidade aos processos que fariam da filha de Joana sua mais nova escrava.

\section{Se a sobrevivência de indivíduos alforriados dependia dos relacionamentos que} desenvolveria em sua vida, pode-se enxergar poderes informais ou mecanismos aperfeiçoados de manutenção da ordem social de Antigo Regime? A promessa de Antônio.

A impossibilidade de dimensionar uma localização temporal exata dos fatos ocorridos com Joana e Francisca torna-se um empecilho para situar os cinco momentos cruciais do caso como um todo. Não se sabe: 1) quando da morte de Úrsula, 2) da resistência de seu marido em entregar a escrava, 3) do momento em que foi renegada por um agente de justiça, 4) da contabilização de sua filha como parte de um inventário e disponibilizada para remate e rematação e 5) da circunstância máxima que levara ao pedido em questão. Sabe-se que pelo menos três anos se passaram, desde que

24 Sobre a ideia de imparcialidade da Relação e da possibilidade de reaver pleitos em favor das camadas consideradas inferiores, ver: SCHWARTZ, Stuart. Burocracia e sociedade no Brasil colonial: o Tribunal Superior da Bahia e seus desembargadores, 1609-1751 - São Paulo: Companhia das Letras, 2011, pp. 148-159. Em pesquisas pessoais, no Arquivo Público da Bahia, em Salvador, no fundo do Tribunal Superior da Bahia, constatei que existiam muitos alvarás de citação e resolução de conflitos por parte de pessoas pretas, pardas e mulatas. Apesar de a grande maioria ser da Bahia, não se descarta a existência de outras Capitanias.

25 De acordo com um suplicante Antonio de Araújo Barbosa, na Vila das Alagoas que clamou, em 1776, resolução de seus conflitos advindos da venda de um bem que herdou, por sua tia, que estava em pendências judiciais, devido sua investida na Relação da Bahia. Fundamentou-se, como licenciado, nas próprias Ordenações do Reino, quando citou "que tal venda foi nula por ser feita de cousa litigiosa contra a expressa disposição da Ordenação, Livro 4", Título 70, parágrafo 3". Arquivo Histórico Ultramarino, Alagoas Avulsos: Documento 209 [23 de fevereiro de 1776], Fl. 01. O regimento mencionado pelo licenciado Antonio Barbosa, no entanto, diz respeito a seu caso especifico, envolvendo bens de herança. Para ais detalhes sobre bens litigiosos, no geral, ver: Ordenações Filipinas: Liv. IV, Tít. X - Das vendas e alheações, que se fazem, de cousas litigiosas. ALMEIDA, Op. Cit., 2012, $3^{\circ}$ Tomo, pp. 787-789. 
Francisca foi comprada, junto com o neto da suplicante, visto as afirmações de que a escrava já tinha tido três filhos desde que a transição de donos foi realizada. Joana teria esperado, ou investido por outras vias, para dar vida aquele requerimento ${ }^{26}$.

Após anos de espera, Joana do Rosário representou ao Conselho Ultramarino acusações de ordem criminal e civil para tentar resolver suas pendências. O motivo que levou a mulher preta forra a pedir interferência do rei em seu caso foi, claramente, como se evidencia em todo o requerimento, a vontade de obter a libertação de sua família. Após apresentar uma série de argumentos sobre promessas e acórdãos que havia estabelecido com mulher e homens de poder social e simbólico na Vila das Alagoas, Joana do Rosário fez questão de enfatizar o quão ela e sua filha estavam de acordo com os princípios básicos do Antigo Regime português.

Ocidentalizar-se ${ }^{27}$ era o ideal de liberdade para um indivíduo forro ${ }^{28}$; esta alternativa asseguraria um melhor acesso ao meio social. Identifica-se uma série de formas de conviver improvisadas por escravos e "pretos forros". O apadrinhamento batismal, organizações sociais representavam a possibilidade de aliviar o cotidiano ${ }^{29}$ e o casamento serviram de vias para alguns daqueles indivíduos conseguirem se manter como agregados em determinadas residências ou mesmo para facilitar o dia-a-dia numa sociedade que dificultava a sobrevivência social de descendentes da África ${ }^{30}$. Hipóteses de relações sociais, que mulheres forras e pretas poderiam possuir para fazer ouvir seus clamores, são as mais plausíveis para compreender o êxito de suas demandas.

Os anos que se passaram desde que Antônio Nogueira arrematou Francisca são estipulados nas mesmas denúncias levantadas por Joana do Rosário. Segundo o requerimento, sob domínio do mesmo homem, a filha da suplicante já havia tido pelo menos três filhos do novo dono. O concubinato foi apontado por Joana como pecado e crime, logo, foi nesse delito moral, de ordem religiosa e secular, que a mulher preta se fundamentou, por seu intermediário representante, para

26 Arquivo Histórico Ultramarino, Alagoas Avulsos: Documento 155 [16 de fevereiro de 1756], Fl. 01 e $01 \mathrm{v}$.

27 GRUZINSKI, Op. Cit., 2014. SÁ, Op. Cit., 2013, pp. 151-270.

28 O ideal de salvaguardar "o direito de ir e vir" não parece ter sido a essência significativa de uma boa vida para escravos de Pernambuco. Para sociedades de Antigo Regime este individualismo que nos é contemporâneo é inviável. Sob a perspectiva de "inserção numa sociedade" como base para a concepção de liberdade de 1822 e de antes disso, tem-se, por exemplo, o uso de pecúlio extra, em formas de lazer como uma maneira de se fazer "livre" ou parte de algum grupo. CARVALHO, Op. Cit., 2001. Para Minas Gerais, cf. FURTADO. Op. Cit., 2003.

29 REGINALDO, Op. Cit., 2001, pp. 27-163.

30 FARIA, Op. Cit., 1998, pp. 289-354. Cf. FRAGOSO, João. "Elite das senzalas e nobreza da terra numa sociedade rural do Antigo Regime nos trópicos: Campo Grande (Rio de Janeiro), 1704-1741”. In: FRAGOSO, João. GOUVÊA, Maria de Fátima. O Brasil Colonial: volume 3 (ca. 1720- ca.1821). - Rio de Janeiro: Civilização Brasileira, 2014. 
estabelecer seu pedido ${ }^{31}$. A partir dessa estratégia argumentativa, Francisca foi apresentada como mulher justa:

[...] tendo já a filha da Suplicante mais tres filhos de que ainda dois existem, chegando a tal cativeiro a sua licenciosa vida, que com asperos castigos obriga a filha da suplicante a prostarse-lhe; por ser esta justa e Catolicamente não quer satisfazer seus ilisitos apetites[... $]^{32}$

Outra acusação latente, complementar aos abusos ou investidas sexuais, tomou forma quando foi afirmado que as respostas negativas e fiéis aos princípios divinos, dadas por Francisca ao seu dono lhe geravam muitos castigos ${ }^{33}$. Enfatizar a devoção daquela mulher parda escravizada era tão importante quanto acusar Antônio Nogueira de maus tratos. A estigmatização de mulheres que não eram brancas foi latente no Antigo Regime nos Trópicos e, sobretudo, no quesito de terem sido interpretadas como uma espécie de encarnação de tudo o que o feminino concorrente no mercado matrimonial não deveria $\operatorname{ser}^{34}$. A forma com a qual Francisca foi apontada lembra a mesma estratégia utilizada por Josefa do Amorim que reivindicava a posse de sua escrava ${ }^{35}$. No requerimento de Joana do Rosário - que pretendia ou alimentava a esperança de ser ouvida pelo rei, seus conselheiros, agentes de justiça e tribunal superior - foi necessário se valer de artifícios para além da cobrança do cumprimento da teórica promessa de alforria ocorrida há pelo menos três anos. As ressalvas sobre o modo de viver e proceder de Antônio Nogueira em relação a sua escrava Francisca foi justificativa básica para aquela solicitação de intermédio e envolvimento de forças maiores de justiça num caso que dizia respeito a um bem privado ${ }^{36}$.

Com um argumento ambíguo como a denúncia de concubinato, era preciso não apenas dar conta a respeito de maus costumes de Antônio, mas também retirar Francisca da sombra que sua qualidade e condição a envolviam em relações ilícitas como aquelas. Assim, a mulher parda assumiu o papel de uma personagem vítima de sua posição e de uma circunstância em desacordo com o que havia sido acordado anteriormente. Do âmbito moral, certamente foram estratégias bem

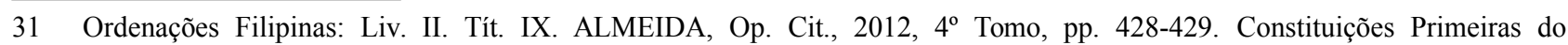
Arcebispado da Bahia: Liv. V, Tít. XXII - Do Con cubinato, § 988. VIDE, Op. Cit., 2010, p. 491. TORRESLONDOÑO, Fernando. A outra família: concubinato, igreja e escândalo na colônia. - São Paulo: Edições Loyola, 1999. FARIA, Op. Cit., 1998. SILVA, Op. Cit., 1984. VAINFAS, Op. Cit., 2010.

32 Arquivo Histórico Ultramarino, Alagoas Avulsos: Documento 155 [16 de fevereiro de 1756], Fl. 01v.

33 "[...] O castigo ficava restrito à esfera de atuação domestica dos senhores. As intervenções de Estado nesse sentido se limitaram à edição de medidas esparsas com vistas a atalhar os excessos cometidos [...]”. JÚNIOR, Op. Cit., 2009, p. 98.

34 Os lugares opostos podem ser visualizados em: VAINFAS, Ronaldo. Trópico dos pecados: moral, sexualidade e inquisição no Brasil. - Rio de Janeiro: civilização brasileira, 2010. FREYRE, Gilberto. Casa Grande \& Senzala: Formação da família brasileira sob o regime da economia patriarcal. São Paulo: Global, 2006. SILVA, Op. Cit., 1984.

35 Arquivo Histórico Ultramarino, Alagoas Avulsos: Documento 45 [19 de maio de 1727], fl. 15.

36 Arquivo Histórico Ultramarino, Alagoas Avulsos: Documento 155 [16 de fevereiro de 1756], Fl. 01 e 01v. JÚNIOR, Op. Cit., 2009, p. 98. LARA, Op. Cit., 1988. SOARES, Op. Cit., 2011. 
utilizadas ou as únicas disponíveis, sobretudo, a indicação do sofrimento físico que a filha de Joana sofria todas as vezes que se negava a ceder "serviços" sexuais ao seu senhor ${ }^{37}$. Contudo, apesar de todos os obstáculos que aquela mãe forra deve ter precisado superar para compor aquele pedido, existiam ainda elementos essenciais não precisamente explicados ou destrinchados. O discurso é tão frágil quanto preciso. Isso se torna visível quando nos fazemos a pergunta básica sobre a carta de manumissão e promessa de Antônio Nogueira. Esses pactos ou acórdãos realmente existiram?

Mesmo que o texto daquele requerimento demonstrasse ou comprovasse a devoção de Francisca e os maus costumes de Antônio Pinto, fica-nos evidente que existia uma dependência pela parte de cada indivíduo à sua função social designada. Forças invisíveis, mas concretas, violentas e excludentes eram forjadas como "naturais" mesmo aos animais e legítima por estar de acordo com o que deus desejava. Assim, por mais que seja complexo de se refletir até que ponto Joana do Rosário era uma mulher vista realmente dentro dos princípios fundamentais católicos e portugueses, essa é uma linha de raciocínio que não pode ser deixada de lado. Lá estava a mulher preta, forra, mas nada satisfeita. Lutava com os meios que lhe estavam disponíveis para se manter junta à sua família, para libertar sua filha e seu neto. Através de associação em irmandades religiosas ou de ativação de redes de sociabilização que lhe podem ter sido abertas por uma série de atividades que estava habilitada a realizar naquela Vila das Alagoas, Joana do Rosário conseguiu ultrapassar a justiça ordinária com seu requerimento ${ }^{38}$. Queria mais do que o que um juiz local poderia oferecer em sua alçada, clamava o auxílio devido do Ouvidor da Comarca para ativação de seu pleito pela Relação da Bahia, como julgava de seu direito ${ }^{39}$.

É provável que seu representante tenha tido a noção da relevância ou complexidade do caso, e que, por isso, tenha almejado o envolvimento do episódio em outras instâncias. Outros simples objetivos podem ser citados como motivadores da ação jurídica. Para evitar qualquer desvantagem que pudesse vir a sofrer diante da posição social de Antônio Nogueira Pinto, a opção mais indicada seria, justamente, diante daquela perspectiva, o apelo para outros âmbitos judiciais considerados mais imparciais e mais certeiros ${ }^{40}$. $\mathrm{O}$ receio da concorrência da Justiça com as redes clientelares de Antônio Nogueira, foi explicitado pela via de um discurso, no mínimo, desafiador da lei. O dono da

37 A atitude de Antônio Pinto está até na simples norma a respeito da obrigação dos donos em transpassar a vida cristã aos seus escravos. Constituições Primeiras do Arcebispado da Bahia: Liv. I, Tít. II - Como são obrigados os pais, mestres, amos e senhores a ensinar ou fazer ensinar a doutrina cristã aos filhos, discípulos, criados e escravos. VIDE, Op. Cit., 2010, pp. 126127. VAINFAS, Op. Cit., 2010. FREYRE, Op. Cit., 2006. FURTADO, Op. Cit., 2003.

38 A ajuda das Irmandades foi estipulada em trabalhos como: REGINALDO, Op. Cit., 2001. VIANA, Op. Cit., 2007.

39 "[...] alegando ser verdade o que alega, remeta o próprio sumario a Relação da Bahia para se julgar que for justiça [...]" Arquivo Histórico Ultramarino, Alagoas Avulsos: Documento 155 [16 de fevereiro de 1756], fl. 01v.

40 SCHWARTZ, Op. Cit., 2011. CAMARINHAS, Nuno. Juízes e administração da justiça no Antigo Regime. Portugal e o império colonial, séculos XVII e XVIII. Lousã: Fundação Calouste Gulbenkian e Fundação para a ciência e a tecnologia, 2010. 
parda Francisca, e pai de três de seus filhos, não era apenas de um "homem poderoso naquela vila" ele era "e ainda temido das justiças". Seus mecanismos para fazer manutenção de interesses foram colocados com a potência máxima de aterrorizar a execução do Direito na região ao qual pertencia $^{41}$.

É o suplicado poderoso naquela vila, e ainda temido das justiças; a filha da suplicante uma pobre parda reputada [corroído] sem meios para conseguir a liberdade que de direito por dois princípios lhe compete; um porque o suplicado prometeu [corroído] e outro porque coabitado com ela; como é público e notório $[\ldots]^{42}$

As falhas ou pontos frágeis do instrumento oficial produzido em nome de Joana do Rosário serão apontadas devidamente. Por hora, diga-se que o maior empecilho existente e dificulto para análise intensa deste documento está relacionado com o fato de não se haver um despacho conclusivo. Nunca poderemos saber no que deu aquele pedido, como foi avaliado, sobre pareceres ou informações concedidas pelo ouvidor competente que deve ter sido consultado caso o documento tenha chegado em suas mãos. Mesmo que o ministro régio tenha sido devidamente solicitado a resolver o caso, ou a tirar devassas e querelar com Antônio Nogueira, é difícil considerar uma vitória da família escravizada. A não visualização ou consideração de que aquele requerimento tenha tido resultados vantajosos para Joana do Rosário, não advém unicamente do fator mais evidente de um direito de propriedade estar sendo contestado. As acusações apontavam para uma promessa não registrada oficialmente, enfatizava uma carta de manumissão que foi perdida e que talvez até mesmo anulada, depois de concretizada a negociação de Joana com Antônio. O que se propõe a observar aqui é a posição social dos que estiveram envolvidos no pleito. É apenas uma questão de se perceber que em 1756, na Vila das Alagoas, região afastada do centro jurídico oficial da América portuguesa, toda tentativa de interpretar o processo de Joana com as fragilidades predeterminadas como passível de êxito anulam as possibilidades existentes para o lado dominante da situação.

Joana do Rosário queria livrar sua filha e neto de um homem branco ou de poder reconhecido localmente. Para tais feitos, se valeu da representação através de outro indivíduo masculino o qual não se pode afirmar as verdadeiras motivações de colaboração no pleito. Partindo dessa linha de raciocínio observa-se que seria essencial poder responder se o requerente que

41 Arquivo Histórico Ultramarino, Alagoas Avulsos: Documento 155 [16 de fevereiro de 1756], fl. 01v.

42 Idem. 
escreveu por Joana estava interessado apenas no que viria receber, financeiramente falando, ou se se tratava mesmo de um contato de amizade ou rede de sociabilização outras. Sua posição e capacidade de falar em juízo, diferente de Joana e Francisca, por suas posições, mas também por seu sexo poderia ser superior a de Antônio Nogueira, mas há de se considerar que da mesma maneira que as mulheres subalternizadas não estavam sozinhas, o dono da parda contaria com seus círculos de poder com maior ou menor intensidade.

Um questionamento básico e quase ingênuo, devido a complexidade de sua incisão, pode ser levantado para a análise de casos como o de Joana do Rosário. Estaria, em 1756, a população masculina detentora de posição majoritária, como receptáculo das mais variadas formas de Justiça, na Vila das Alagoas, disposta a aceitar indivíduos advindos de camadas "inferiores" em âmbitos jurídicos? E mais, estariam abertos a solicitações de homens e mulheres pretas que implicavam gente "poderosa" da terra e "temida" pela justiça? Uma comprovação de que perante situações como essas, os grupos mais bem posicionados ainda resistiam em aceitar novas "condições" impostas a gente de "qualidade" inferior, pode ser vista na própria ideia da consecução de elementos dominantes sob indivíduos que haviam sido escravizados. Essa sujeição servia como uma espécie de manutenção de um laço senhor-escravo ${ }^{43}$ que não existia mais apenas no âmbito formal.

A identificação desses elementos desmascara a ideia de naturalização das coisas e seres humanos no grosso do pensamento jurídico e teológico português do Antigo Regime. Estratégias, mecanismos informais de poder e maneiras de lidar estavam disponíveis em níveis diferentes, pois também dependeria dos fatores extras para além do que o cotidiano podia ocasionar. Não se pretende transpassar nenhuma concepção extremamente rígida de uma Justiça do rei ou local nas possessões portuguesas ultramarinas. Apenas é preciso analisar com mais profundidade o aparecimento de personagens como Joana do Rosário em pleitos contra indivíduos tidos por "mais dignos", fosse pelo sexo ou pela posição dentro daquele mundo lusitano católico. Em busca de não apresentar ambos os casos como desprovidos de atitudes de poder advindos daquelas mulheres pretas forras da Comarca das Alagoas, é preciso ressaltar que mesmo a computação de hipóteses que as troquem do lugar de vítimas, demonstra o caráter de um Direito e Justiça que prezam a manutenção da propriedade e moral de homens privilegiados.

Joana do Rosário, em seu requerimento, afirmava a existência de uma Carta de Manumissão 1988.

43 CARVALHO, Op. Cit., 2001, pp. 213-324. JÚNIOR, Op. Cit., 2009. 2011, pp. 35-65. LARA, Op. Cit., 
para sua filha, concedida pela dona, Úrsula de Brito, porém, a perda ou ausência do documento indicado em todo o pleito instiga o historiador a se questionar sobre até que ponto aquele comprovante realmente existiu. No século XVIII muitas pessoas eram analfabetas ${ }^{44}$, daí o forte apego e apelação para estabelecer uma série de aspectos visuais no Direito e Religião ${ }^{45}$. Como mulher preta e forra, a probabilidade de que soubesse ler ou reconhecer uma real carta de alforria é muito baixa. Dependendo da forma que Úrsula conferiu a libertação de Francisca, pode ser que Joana tenha sido enganada não apenas por Simão Luiz, mas desde o "benefício" prestado por sua esposa. Informações como esta seriam capazes de responder se tal carta chegou a ser escrita e registrada $^{46}$, se um documento real foi visto por Joana (que certamente não o saberia discernir) ou se tratou apenas de um acordo "de boca" entre aquelas duas mulheres.

Serviços prestados ou adaptação a situação degradante que era a escravidão, podem ter sido os únicos mecanismos possíveis de serem utilizados por escravos e escravas, em nome de com a comoção ou morte do dono(a) conseguir alforria, por compra ou concessão, ambas as maneiras consideradas "graças". Assim, a relação que Francisca e sua mãe mantiveram com Úrsula de Brito pode ter fundamentado, senão o registro da alforria propriamente dito, ao menos uma promessa cobrada. Além dessas opções, Joana do Rosário pode ter simplesmente forjado a "dádiva" ou "juramento" da esposa de Simão, sobretudo, baseada na argumentação da ausência de herdeiros do casal e numa ligação reconhecidamente não conflituosa entre senhora e escrava. A morte de um senhor era uma oportunidade utilizada por escravos para tentar se livrar da servidão ${ }^{47}$.

É possível que Simão Luiz sequer soubesse da existência da carta ou da "amizade" ou "negociação" entre aquelas mulheres. Se a escrava pertencesse a sua esposa é possível que tenha se valido do direito para conceder a liberdade a uma propriedade sua sem o intermédio do marido. Mas dentre essas alternativas a mais interessante e que não há como se negar é que o "ministro", provavelmente, não aceitou a querela justamente pela ausência da "prova" que daria sustância a todo o pleito. Ora, a própria Joana do Rosário alertou sobre esse documento não ter sido localizado, dessa feita, um oficial da Justiça não poderia, nem procederia - mesmo que não tivesse objeções, pelo regimento e seus ideais - com uma querela ou "citação", advinda de uma mulher preta forra que tinha como principal objetivo excluir ou relativizar o direito de propriedade de um homem

44 Sobre índices de analfabetismo, ver: LARA, Op. Cit., 2007, pp. 79-172. VILLALTA, Luiz C. "O que se fala e o que se lê: língua, instrução e leitura”. In: MELLO E SOUZA, Laura de. (org.). História da vida privada no Brasil: cotidiano e vida privada na América portuguesa. / coordenador geral da coleção Fernando A. Novais. - São Paulo: Companhia, 1997.

45 MARAVALL, José Antonio. A cultura do Barroco. Análise de uma estrutura histórica. São Paulo: EDUSP, 2009.

46 Sobre a necessidade de registro por Tabelião, ver: LARA, Op. Cit., 1988.

47 SOARES, Op. Cit., 2011. LARA, Op. Cit., 1988. 
branco, senhor provavelmente influente dentro daquele meio, ou ao menos com conduta e imagem de honrado.

Nessa perspectiva, a existência ou afirmação de que uma promessa foi estabelecida entre Joana e Antônio Nogueira, pode demonstrar apenas o interesse daquele homem em Francisca, que o teria levado a sanar possibilidades de apelação para poder realizar seu investimento sem grandes problemas. Essa jogada por parte de Nogueira Pinto é destrinchada a cargo de identificar explicações dentro da hipótese de que a carta de manumissão pode nunca ter existido, mas representado verdadeiro atraso na resolução do inventário de Úrsula, se alcançasse instâncias distantes e superiores. Há de se considerar, para todos os fins, que até mesmo aquele acórdão se tornaria duvidoso e apresenta-se como mais um fator frágil nos argumentos registrados naquele requerimento.

Até mesmo o concubinato descrito por Joana e possível de ser comprovado, segundo ela, pela existência de três filhos de Antônio Nogueira com sua escrava, pode ter tido peso de uma "faca de dois gumes". Ainda estava se falando de uma mulher parda e escravizada, tendo considerável carga de desvantagem para Francisca. Não podemos esquecer que à mulher o crime sempre recebeu maior repressão, já que se tratava apenas de uma característica natural do feminino que não havia sido totalmente controlada. Apesar de "católica", Francisca teria poucas chances em acusar seu senhor, em nome de obter liberdade por conta da "expansão do domínio a posse sexual"48. Lembrese que como servente na casa a qual pertencia, podia ser contabilizada como essencial ao andamento doméstico da residência, logo, livrava seu dono de quaisquer penalizações mesmo que fosse uma espécie de receptáculo para o adultério afirmado pela própria Igreja ${ }^{49}$.

Uma arma que se considera pouco representativa de "resistência" é a apelação para o sexo. Aconselhada pela mãe, ou por sua própria cabeça, Francisca muito bem poderia ter compactuado com as investidas de seu dono ou mesmo as incitado, visto a "promessa" existente sobre sua liberdade e uma pressa em se juntar de vez com sua família. Conceber três filhos de seu senhor não necessariamente significaria que caíra nas graças do dono ${ }^{50}$, contudo, é viável a interpretação destes atos como adaptações às circunstâncias e manipulação, e constituição de poderes informais com o objetivo chave de ser liberta. A relutância em se considerar que essa via possa ser significativa de alguma espécie de "rebeldia" disfarçada não retira dessas determinadas atitudes as características de

48 VAINFAS, Op. Cit., 2010.

49 Constituições do Arcebispado da Bahia: Liv. V, Tít. XXII, § 988. VIDE, Op. Cit., 2010, p. 491.

50 PAIVA, Op. Cit., 1995. 
terem sido o ponto de partida para êxitos cotidianos da parte, sobretudo, de mulheres escravizadas, pretas e subestimadas por questões religiosas e sociais ${ }^{51}$. Apenas aponta-se para uma melhor visualização dos eventos, da situação e meio em que ocorreram e das verdadeiras motivações por traz dessa ultrapassagem dificultosa.

É possível delinear o sexo ou artifícios da sexualidade feminina como via decisiva ou substancial para a consecução da sobrevivência de mulheres pretas, escravas ou forras. É necessário, contudo, buscar interpretações que possam ir além da identificação com determinadas teorias sobre a estratificação do poder ${ }^{52}$. Observar aquelas atitudes mais profundamente não implica em negar essas vertentes de análise, muito menos a capacidade que as mulheres tiveram para forjar essas situações em benefício próprio. Porém, colabora em desmistificar a ideia que essas informações podem passar sobre ser sempre o sexo, à mulher, a via mais possível, bem como outras estratégias que a remetem as mesmas características estipuladas, desde Aristóteles, até as interpretações mais perigosas, realizadas pelo grupo intelectual dominante que fora a Igreja Católica em Portugal ${ }^{53}$. Para enxergar a pluralidade do feminino realmente é aconselhável não legá-la unicamente ao lugar de vítima, mas o olhar voltado para um setor escravizado de uma sociedade inserida num amplo e complexo contexto de Antigo Regime requer cautela na associação do sexo diretamente à "astúcia" das mulheres.

Dito isso, a argumentação do concubinato em mescla com a afirmação da devoção e religiosidade de Francisca são pontos que podem ser alterados de perspectiva quando se considera a linha interpretativa de que Joana e sua filha estavam dispostas a unir sua família a qualquer custo. A sedução ${ }^{54}$ e concepção de três filhos com Antônio Nogueira que parece não ter servido para lhe render a alforria pode, sem grandes dificuldades, ter assumido a posição inversa quando da montagem de acusações contra o senhor de escravos. Chamá-lo de concubinário e se retirar da culpa pode ter sido a melhor estratégia utilizada dentro das fragilidades outras daquele requerimento.

Se o caso tiver sido ativado na Relação da Bahia ainda devem-se considerar as inquirições que seriam realizadas, bem como as argumentações de defesa que não deixariam de vir do lado de Nogueira Pinto. As inconstâncias dos pontos questionados e mesmo o concubinato, utilizados como

51 FURTADO, Op. Cit., 2003.

52 MENDONÇA, Sônia Regina e FONTES, Virgínia. História e teoria política. In: CARDOSO, Ciro Flamarion e VAINFAS, Ronaldo (orgs.). Novos domínios da história. Rio de Janeiro: Campus, 2012, pp. 55-70.

53 HESPANHA, Op. Cit., 2010. PRIORE, Op. Cit., 2009.

54 ARAÚJO, Emanuel. "A arte da sedução: sexualidade feminina na Colônia”. In: DEL PRIORE, Mary (org.). PINKSY, Carla Bassanezi (coord. de textos). História das mulheres no Brasil. - São Paulo: Contexto, 2013. 
eixos centrais daquele discurso serviriam como entraves sob a manipulação de uma arguição defensiva pelo dono de Francisca ou algum agente seu representante. Mesmo tendo consciência da existência da Justiça e a afirmando em palavras, a exatidão de seus "direitos" não é, de todo, certo que viesse a conseguir a tão almejada liberdade. Esses empecilhos eram concretos por suas "qualidades", “condições" e sexo. Ora, quem pode garantir que a pessoa responsável em enviar aquele pedido ao rei acreditava no que estava escrevendo? Jamais se poderá afirmar, nem se podia, sobre as reais intenções do procurador de Joana do Rosário. Certamente, pouquíssimos homens estariam dispostos a comprar briga com aquele que era "poderoso na terra" e "temido pelas justiças" ${ }^{, 5}$. Os obstáculos que o próprio documento apresenta são passíveis de ter sido o resultado de sua produção pelas mãos de alguém que não concebia os direitos que clamava.

\section{Considerações Finais:}

O caso de Joana do Rosário pode ser visualizado como aspectos de poder pela consciência de um estatuto jurídico que a salvaguardaria, pela viabilização do registro e requerimento e por ter almejado adentrar na interseção da justiça do rei. Mesmo com a ausência de um despacho que nos diga mais sobre a resolução do litígio em si, não são desconsideráveis os momentos em que a argumentação demonstra uma posição relativamente vantajosa. Isso, no entanto, deve ser visto com muito cuidado. Não se tratava de uma forma de exercer pressão ao meio, pois viu-se que, na verdade, ambas as mulheres envolvidas foram constantemente levadas a atingir o ápice das adaptações ao pensamento político luso-brasileiro vigente.

Quando a justiça local não deu solução, Joana, preta, forra, buscou outros meios de atingir a resolução dos conflitos nos quais esteve envolvida. Apesar de requerer a partir de um primeiro olhar, a submissão de suas pendências litigiosas a um aparato externo a Vila das Alagoas, não se pode deixar de observar o tipo de discurso que para aquela mulher ou para seu representante, poderia ter valor de convencimento. Não bastava confrontar as promessas não cumpridas de Antonio, era preciso esclarecer os pontos principais da longa batalha pela liberdade de Francisca. Assim, tem-se a afirmação de uma "carta de liberdade", mas na ausência da mesma apenas o preenchimentos de lacunas a respeito de uma conduta poderiam fazer o efeito esperado. Ao chegar no assunto do concubinato mencionou-se sobre a fama de Antônio Nogueira na Vila de Alagoas, na tentativa de justificar a necessidade da Relação da Bahia. Além disso, contrastou-se a posição do

55 Arquivo Histórico Ultramarino, Alagoas Avulsos: Documento 155 [16 de fevereiro de 1756]. 
acusado e da vítima, demonstrando que Francisca teria que ser livre, por um direito que lhe era garantido devido as relações ilícitas que fora obrigada a desenvolver.

Tudo isso pode fazer parecer que a literatura jurídica e a atuação de agentes da justiça ou do rei perante a resolução de crimes e conflitos outros funcionava de maneira igualitária. Porém, antes de sermos abraçados pela ideia tentadora de finalizar esse texto nos adequando as teorias mais recentemente acordadas onde a mobilidade social é sempre possível na América portuguesa, vale atentar não apenas o estender dos anos em que Joana e sua filha tiveram que se assistir inertes diante de toda aquela situação. As argumentações de defesa e acusação que davam fundamento a concessão régia podiam ser evidência de um "projeto" cultural português que obtinha êxito. Ora, uma mulher preta defendia sua filha de um concubinato e legitimava uma acusação dessa ordem com o encaixe de Francisca como mulher católica.

Tais artifícios, e tantos outros que tentou-se mostrar nesse texto, foram identificados não no intuito de generalizar um estudo de caso a outras vivências e ao cotidiano de escravos e libertos na América portuguesa do século XVIII. Através desse estudo quer-se atentar para a necessidade de interpretação e problematização profunda e exaustiva quando se trata de relações estabelecidas entre indivíduos de camadas distintas da sociedade colonial.

\section{Referências Documentais e Bibliográficas}

Arquivo Histórico Ultramarino, Alagoas Avulsos, Documento 10 [26 de maio de 1712]

Arquivo Histórico Ultramarino, Alagoas Avulsos: Documento 45 [19 de maio de 1727]

Arquivo Histórico Ultramarino, Alagoas Avulsos: Documento 155 [16 de fevereiro de 1756].

Arquivo Histórico Ultramarino, Alagoas Avulsos: Documento 209 [23 de fevereiro de 1776]

ALMEIDA, Cândido Mendes de. Código Filipino, ou, Ordenações e Leis do Reino de Portugal: recopiladas por mandado d'el Rey D. Filipe I / Cândido Mendes de Almeida. Ed. Fac-sim. Brasília: Senado Federal, Conselho Editorial, 2012.

VIDE, Sebastião Monteiro da. Constituições Primeiras do Arcebispado da Bahia. Istvan Jancsó, Pedro Puntoni (org.). - São Paulo: Editora da Universidade de São Paulo, 2010.

ALMEIDA, Suely Creusa de. "Histórias de gente sem qualidades: mulheres de cor na capitania de Pernambuco no século XVIII”. In: CABRAL, Flávio José Gomes \& COSTA, Robson. 
História da Escravidão em Pernambuco. Recife: UFPE, 2012.

ARAÚJO, Emanuel. "A arte da sedução: sexualidade feminina na Colônia". In: DEL PRIORE, Mary (org.). PINKSY, Carla Bassanezi (coord. de textos). História das mulheres no Brasil. - São Paulo: Contexto, 2013.

BARDIN, Laurence. Análise de Conteúdo. Lisboa, Edições 70.

CAMARINHAS, Nuno. Juízes e administração da justiça no Antigo Regime. Portugal e o império colonial, séculos XVII e XVIII. Lousã: Fundação Calouste Gulbenkian e Fundação para a ciência e a tecnologia, 2010.

FARIA, Sheila de Castro. "Damas mercadoras: as pretas minas no Rio de Janeiro (século XVIII1850)". In: SOARES, Mariza Carvalho. (Org.) Rotas Atlânticas da Diáspora Africana - da Baía do Benim ao Rio de Janeiro. Niterói: EDUFF, 2001.

FRAGOSO, João. "Elite das senzalas e nobreza da terra numa sociedade rural do Antigo Regime nos trópicos: Campo Grande (Rio de Janeiro), 1704-1741”. In: FRAGOSO, João. GOUVÊA, Maria de Fátima. O Brasil Colonial: volume 3 (ca. 1720- ca.1821). - Rio de Janeiro: Civilização Brasileira, 2014.

FREYRE, Gilberto. Casa Grande \& Senzala: Formação da família brasileira sob o regime da economia patriarcal. São Paulo: Global, 2006.

FURTADO, Júnia Ferreira. Chica da Silva e o contratador dos diamantes: o outro lado do mito. - São Paulo: Companhia das Letras, 2003.

GRUZINSKI, Serge. As quatro partes do mundo. História de uma mundialização. Belo Horizonte, Editora UFMG; São Paulo, Edusp, 2014.

HESPANHA, António Manuel. "Fundamentos antropológicos da família de Antigo Regime: os sentimentos familiares". In: HESPANHA, António Manuel (coord.). História de Portugal, o antigo regime (vol. IV). Dir. José Mattoso. Lisboa: editorial estampa, 1992.

HESPANHA, António Manuel. O direito dos letrados no Império português. Florianópolis: Fundação Boiteux, 2006.

HESPANHA, António Manuel. “A mobilidade social na sociedade de Antigo Regime”. Revista Tempo. Rio de Janeiro, n 21, volume 11, julho de 2006.

HESPANHA, António Manuel. “Antigo regime nos trópicos? Um debate sobre o modelo político do império colonial português". In. FRAGOSO, João. Gouvêa, Maria de Fátima (orgs.). Na trama das redes: política e negócios no império português, séculos XVI - XVIII. - Rio de Janeiro: Civilização Brasileira, 2010.

HESPANHA, António M. Imbecillitas: As bem-aventuranças da inferioridade nas sociedades de Antigo Regime. São Paulo: Annablume, 2010.

JÚNIOR, Waldomiro Lourenço da Silva. A Escravidão e a Lei: gênese e conformação da tradição legal castelhana e portuguesa sobre a escravidão negra na América, séculos XVIXVIII. 2009. Dissertação (Mestrado em História) - Universidade de São Paulo, São Paulo, 
2009.

LARA, Silvia Hunold. Campos da Violência: escravos e senhores na Capitania do Rio de Janeiro, 1750-1808. Rio de Janeiro: Paz e Terra, 1988.

LARA, Silvia Hunould. Fragmentos Setecentistas: Escravidão, cultura e poder na América Portuguesa. São Paulo: Companhia das Letras, 2007.

TORRES-LONDOÑO, Fernando. A outra família: concubinato, igreja e escândalo na colônia. São Paulo: Edições Loyola, 1999.

MAESTRI, Mário. "Como era gostoso ser escravo no Brasil: A apologia da servidão voluntária de Kátia de Queirós Mattoso". Revista Crítica Histórica. Ano VI, n 12, dezembro de 2015. Disponível em <http://www.revista.ufal.br/criticahistorica/attachments/article/256/Fluxo \%201.pdf $>$ Acessado em 25/03/2017.

MARAVAll, José Antonio. A cultura do Barroco. Análise de uma estrutura histórica. São Paulo: EDUSP, 2009.

MELLO, Evaldo Cabral de. O nome e o sangue: uma parábola familiar no Pernambuco colonial. $2^{\mathrm{a}}$ edição revista. - Rio de Janeiro: Topbooks, 2000.

MENDONÇA, Sônia Regina e FONTES, Virgínia. História e teoria política. In: CARDOSO, Ciro Flamarion e VAINFAS, Ronaldo (orgs.). Novos domínios da história. Rio de Janeiro: Campus, 2012.

PAIVA, Eduardo França Paiva. Escravos e libertos nas Minas Gerais do século XVIII estratégias de resistência através dos testamentos. São Paulo: Annablume, 1995.

REGINALDO, Lucilene. Os Rosário dos Angolas: irmandades de africanos e crioulos na Bahia Setecentista. São Paulo: Alameda, 2001.

SÁ, Elaine Garcindo de. Mestiço: entre o mito, a utopia e a história - reflexões sobre a mestiçagem. Rio de Janeiro: Quartet: Faperj, 2013.

SCHWARTZ, Stuart. Burocracia e sociedade no Brasil colonial: o Tribunal Superior da Bahia e seus desembargadores, 1609-1751 - São Paulo: Companhia das Letras, 2011

SILVA, Maria Beatriz Nizza da. "A cultura explícita". In: MAURO, Frédéric (coord.). Nova história da expansão portuguesa: o império luso-brasileiro, 1620-1750. Direção de Joel Serrão e A. H. de Oliveira Marques. - Lisboa: Editorial Estampa, 1991.

SOARES, Márcio de Sousa. "A promessa da alforria e os alicerces da escravidão na América portuguesa". In: GUEDES, Roberto. Dinâmica imperial no Antigo Regime português: escravidão, governos, fronteiras, poderes, legados: Séc. XVII-XIX. Rio de Janeiro: Mauad X, 2011.

THORTON, John. A África e os africanos na formação do mundo atlântico. 1400-1800. Rio de Janeiro: Elsevier, 2004.

VAINFAS, Ronaldo. Trópico dos pecados: moral, sexualidade e inquisição no Brasil. - Rio de 
Janeiro: civilização brasileira, 2010.

VILLALTA, Luiz C. "O que se fala e o que se lê: língua, instrução e leitura". In: MELLO E SOUZA, Laura de. (org.). História da vida privada no Brasil: cotidiano e vida privada na América portuguesa. / coordenador geral da coleção Fernando A. Novais. - São Paulo: Companhia, 1997. 